\title{
¿TIENEN DERECHOS LOS MUERTOS?
}

\author{
Do THE DEADS HAVE RIGHTS?
}

\author{
Ronald Cárdenas Krenz \\ Universidad ESAN, Perú \\ https:/ / orcid.org/0000-0002-1777-9423
}

\section{Resumen}

El presente estudio revisa algunos conceptos comunes del derecho, como el paradigma de que la persona, al morir, se vuelve un objeto, poniendo en cuestión la idea tradicional de que los derechos del ser humano se extinguen con su fallecimiento. Se plantea, asimismo, la posibilidad de su reconocimiento a partir del concepto de "personalidad pretérita trascendente» y teniendo en cuenta la dignidad póstuma de la persona. Para el efecto, se analiza el tema tanto desde una perspectiva teórica como práctica, buscando ofrecer una perspectiva más completa para la mejor protección y defensa de los derechos fundamentales, entre otras cuestiones vinculadas con la materia.

Palabras clave: derechos post mortem, personalidad pretérita, efectos de la muerte, significado de la muerte, dignidad póstuma.

\begin{abstract}
The study reviews some common concepts about Law, such as the paradigm that the person becomes an object with death, laying down in question the traditional idea that the rights of the human being are extinguished with his death, raising the possibility of their recognition through the concept of "transcendent preterit personality" and taking into account the posthumous
\end{abstract}


dignity of the person. To this end, the subject is analyzed both from a theoretical and a practical perspective, offering a more complete perspective in the better defense and protection of the Fundamental Rights, among other issues related to the subject.

Keywords: Post mortem rights, past personality, effects of death, meaning of death, posthumous dignity.

\section{Introducción ${ }^{1}$}

Suele repetirse que, con la muerte, la persona pasa de ser sujeto de derecho a convertirse en objeto de derecho. Sin embargo, ¿en realidad esto es así? ¿Puede considerarse al cadáver un simple objeto? Muerta una persona, ¿no queda nada de su personalidad? ¿Cómo explicar que deban respetarse las disposiciones de voluntad del difunto si, cuando ellas lleguen a ser exigibles, él ya no es titular de derechos?

La cuestión no solo es interesante por motivos teóricos, sino también eminentemente prácticos, a fin de poder sustentar de una mejor manera el respeto de diversas disposiciones post mortem (como la cesión de órganos), el tratamiento respetuoso del cadáver en hospitales y facultades de medicina, la defensa del honor de las personas fallecidas, la consideración del estatus de cadáver del concebido, etc. Asimismo, la reflexión puede ser útil para evitar el exhibicionismo, revisar disposiciones legales, como aquella que establece que mayor sanción tiene quien roba la sortija de una difunta que quien la violenta sexualmente, o evitar que la profanación de tumbas quede reducida a una mera falta. Para el correspondiente análisis, debemos considerar, como punto de partida, la connotación social y cultural que tiene un cadáver.

Al morir una persona, en efecto se extingue su existencia física, mas no desaparece por completo. No solo porque igual podemos seguir hablando de ella, sino porque le perviven relaciones, decisiones tomadas, los hijos que tuvo, sus obras publicadas, los recuerdos que dejó, las disposiciones testamen-

1 El presente estudio ha sido realizado con el auspicio del Instituto de Investigación Científica (IDIC) de la Universidad de Lima y contó con la valiosa colaboración, como asistente de investigación, de Sandra Rovegno Loayza, estudiante de la Facultad de Derecho de dicha casa de estudios. 
tarias de su patrimonio o su buen nombre. Como observa Trigg, «el hombre no es nada sin su biología, se expresa a través de su cultura, y tiene también el poder de trascenderlas» ${ }^{2}$.

Somos existencia y trascendencia. Con la muerte, dejamos de ser sujetos de derecho, pero igual, de diversas maneras, nuestra vida sigue proyectándose más allá de nuestra presencia física.

Sabemos que, tras el deceso de la persona, se debe ejecutar su voluntad expresada en su testamento, corresponde la ejecución del seguro de vida que contrató y debe respetarse su voluntad de donar sus órganos. Entonces, ¿Cómo explicar que deban cumplirse tales deseos de un sujeto cuando ya no es persona?

No cabe duda de que la memoria de un difunto debe ser respetada, que se debe tratar con respeto su cadáver, mas ¿qué es lo que subyace a dichos deberes? ¿Son meras obligaciones morales o acaso tienen trascendencia jurídica?

La reflexión sobre estas cuestiones se torna más importante si se tiene presente que «la protección post mortem de los derechos de la personalidad no ha gozado de un extenso tratamiento por parte de la doctrina civilista ${ }^{3}$.

A las complejidades que conlleva el tema de la muerte, se agregan cuestiones vinculadas con el desarrollo tecnológico, el cual plantea nuevas interrogantes relacionadas con la posibilidad de la criogenia o criopreservación de cadáveres, por ejemplo.

Otras cuestiones por abordar son la respuesta que debe dar el derecho a los usos atípicos de un cadáver o los alcances jurídicos de la voluntad del difunto, cuando se trata de las disposiciones funerarias de su cuerpo; en este particular, un caso curioso es lo que, por ejemplo, ocurre en Puerto Rico, donde a una persona se la veló sentada en su motocicleta porque así lo había pedido en vida, mientras otra fue velada en su auto. Estos y otros casos similares nos llevan a pensar desde otro ángulo el tema de la autonomía de la voluntad y sus límites.

Existe también el caso de la exposición «El cuerpo humano real y fascinante», del artista alemán Gunther von Hagens, en la que se exhiben los restos

2 Roger Trigg, Entre la cultura y la genética. Aspectos filosóficos de la sociobiología (México: Fondo de Cultura Económica, 1989), 250.

3 Mercedes Ramos Gutiérrez, «La protección de la memoria defuncti» (tesis doctoral, Universidad de Salamanca, 2012), http://gredos.usal.es/jspui/bitstream/10366/121403/1/DDP_RamosGutierrezMercedes_Tesis.pdf 
preservados de personas fallecidas. Si bien la ley permite el uso de cadáveres para fines didácticos, la pregunta es si ello en realidad se cumple en este caso o si estamos más bien ante un lucrativo $-\mathrm{y}$, por tanto, ilegal- negocio. Cabe mencionar que, cuando fue presentada en el Perú, la exposición terminó de forma escandalosa luego de que se descubrió que el supuesto robo del pulmón de uno de los cadáveres — denunciado por los organizadores—había sido una vil farsa publicitaria.

En virtud de todo lo expuesto, el objetivo principal del presente estudio es determinar si debe reconocerse a las personas fallecidas la posibilidad de ser titulares de derechos. A su vez, como objetivos específicos se plantean: a) definir los derechos que, en todo caso, le serían subyacentes al fallecido; b) analizar algunas cuestiones prácticas vinculadas con la materia respecto a las cuales existe defecto o deficiencia de la ley.

Como hipótesis de trabajo, partimos de las siguientes:

Primera hipótesis. Las personas fallecidas, aunque con su muerte dejan de ser sujetos de derecho, mantienen algunos que les perviven. Adquieren, de esta manera un estatus especial.

Segunda hipótesis. Existen disposiciones del fallecido que son de obligatorio cumplimiento, sin que los familiares puedan oponerse a ellas.

Tercera hipótesis. Debe optimizarse la legislación y la interpretación judicial en el tratamiento de algunas materias específicas, como en el caso del concebido no nacido, la disposición de los órganos de la persona en general, el uso de los cadáveres o el destino de las cenizas de los difuntos, tema sobre el que recientemente se pronunció el Vaticano, y que generó diversas opiniones, a la vez que puso en evidencia la escasa regulación legal de la materia por parte de los Estados ${ }^{4}$, el manejo de los casos de criopreservación y la disposición de los genes del fallecido, entre otras cuestiones.

En cuanto a la metodología empleada, se trata de un estudio doctrinario, legislativo y jurisprudencial que considera tanto el derecho peruano como el comparado. Es, asimismo, una investigación de naturaleza cualitativa, bibliográfica y descriptiva, sobre la base del reconocimiento de los derechos fundamentales, partiendo de una perspectiva humanista.

4 Siendo una práctica común la cremación de cadáveres, existe escasa regulación sobre el estatus de las cenizas. En el Perú se cuenta apenas con una norma genérica en el artículo 318 del Código Penal. 
Por último, el estudio busca facilitar un mejor tratamiento de la materia por parte de los magistrados y operadores del derecho, planteando algunos temas para el debate, a la vez que contribuir a una mejor interpretación de los derechos fundamentales.

\section{Naturaleza jurídica del cadáver: ¿de sujetos a meros objetos?}

Para determinar si puede considerarse que los muertos tienen derechos o no, es esencial partir de la definición de la naturaleza jurídica del cadáver. De acuerdo con el ordenamiento jurídico, una vez que la persona muere, se convierte de sujeto en objeto de derecho, siendo los sistemas legales muy claros al respecto:

- «La existencia de la persona humana termina por su muerte» (art. 93 del Código Civil argentino).

- «La existencia de la persona natural termina con la muerte» (primera parte del art. 10 del Código Civil brasileño).

- «La persona termina con la muerte natural» (art. 78 del Código Civil chileno).

- «La persona termina en la muerte natural» (art. 94 del Código Civil colombiano).

- «La personalidad se extingue con la muerte de la persona» (art. 62 del Código Civil español).

- «La muerte pone fin a la persona» (art. 61 del Código Civil peruano).

De esta manera, el desconocimiento de derechos al cadáver parece derivarse de una simple inferencia lógica: una vez que la persona pierde su condición de sujeto de derecho, pierde, entonces, toda posibilidad de ser titular de derechos. Este razonamiento, sin embargo, suena demasiado simplista, pues, para empezar, no puede considerarse al cadáver como un mero objeto, ya que se trata, en todo caso, de un objeto sui generis. Además, debemos recordar que la muerte tiene un carácter jurígeno, es decir, genera consecuencias jurídicas.

$\mathrm{Y}$ es que los intereses y relaciones de la persona pueden proyectarse más allá de su muerte. Como dice Cantor: «Dead people have a variety of personal interests that can be affected by posthumous events. [...] American culture 
and law rightly recognize post-mortem interests and even legal rights belonging to the corpse itself $»^{5}$.

Si bien el cadáver ya no es un sujeto, existe una prolongación última (o póstuma) de la personalidad, la cual genera diversos efectos, como veremos en las siguientes páginas.

\section{Efectos jurídicos ordinarios de la muerte}

La muerte es un hecho biológico que genera diversos efectos jurídicos:

- Los bienes pasan a los herederos (art. 660 del Código Civil peruano).

- Se debe ejecutar el testamento, si lo hubiera.

- Deviene en exigible el seguro de vida.

- La disposición de la imagen, intimidad o voz del fallecido solo podrá hacerse con autorización de los herederos.

- Quedan sin efecto la designación de curador o la distribución realizada de los bienes en caso de declaración de ausencia (art. 59 del Código Civil peruano).

- Se disuelve el matrimonio y concluye la unión de hecho. Fenece la sociedad de gananciales (art. 318 del Código Civil peruano).

- Se extingue la obligación alimentaria (art. 486 del Código Civil peruano), la patria potestad (art. 461 del Código Civil peruano) y la tutela (art. 549 del Código Civil peruano).

- Quedan sin efecto todas las obligaciones personalísimas (art. 1218 del Código Civil peruano), y las no personalísimas son asumidas por los herederos.

- Se extinguen el usufructo (art. 1021 del Código Civil peruano), el derecho de uso y el de habitación (art. 1026 y 1029 del Código Civil peruano).

- Se extingue el albaceazgo (art. 796 del Código Civil peruano).

- Empieza a correr el tiempo para que una obra se declare de dominio público.

- Caduca la oferta (art. 1387 del Código Civil peruano).

- Caduca el mandato (art. 1801 del Código Civil peruano).

- Se extingue el comodato en determinadas circunstancias.

5 Norman L. Cantor, After We Die: The life and times of the human cadaver (Washington DC: Georgetown University Press, 2010), 31. 
- Se extingue la renta vitalicia y el contrato de prestación de servicios (art. 1763 del Código Civil peruano).

- Se pierde la capacidad procesal.

- Se archiva cualquier juicio por responsabilidad penal contra el fallecido.

- Debe ejecutarse la cesión de órganos post mortem dispuesta en vida por la persona.

- Se hace efectivo el derecho a la sepultura.

Como parte del derecho civil, el derecho sucesorio regula la sucesión mortis causa, incluyendo la transmisión de los bienes, derechos y obligaciones de una persona después de su fallecimiento; mas lo que nos interesa aquí no es lo que el fallecido pueda transmitir a otro, sino lo que pueda corresponderle a él aun después de muerto; de esta manera, el énfasis del estudio de los derechos post mortem de la persona no recae en los bienes, sino en la persona en sí misma después de muerta.

\section{Disposiciones inmediatas vinculadas con la muerte}

Más allá de los efectos que, en general, produce la muerte, existen una serie de cuestiones inmediatas que deben ser atendidas: el velatorio del cadáver, su entierro, la decisión de enterrarlo o cremarlo, etc.

Las instrucciones que pueda haber dado el fallecido o lo que, en su defecto, decidan sus familiares, tienen entre sus límites la ley, el orden público, las buenas costumbres, las normas del lugar del velatorio o del cementerio, los principios generales del derecho, razones de salubridad, etc., como también las creencias morales, religiosas o culturales del difunto, la moral social y la costumbre.

Siguiendo a Morelli, puede decirse que, habiendo sido el cadáver parte constitutiva y consustancial de una persona, «[p]arece razonable por ello admitir cierto respeto por las decisiones de las personas respecto del destino de su cadáver, como una manifestación post mortem de su dignidad, libertad y responsabilidad personal $»^{6}$.

6 Mariano G. Morelli, «Extracción de órganos de cadáveres con fines de trasplante. Voluntariedad y consentimiento presunto», Vida y ética, n. ${ }^{\circ} 2$ (2009), 10, https://repositorio.uca.edu.ar/ bitstream/123456789/1504/1/extraccion-organos-cadaveres-consentimiento-presunto.pdf 
Todo ello se vincula con «el significado filosófico, social y cultural de la muerte, siendo la actitud ante la muerte un rasgo distintivo del ser humano como especie, pues somos los únicos animales que enterramos a nuestros muertos» ${ }^{7}$.

\section{Acerca del derecho a la sepultura y otras cuestiones}

«El derecho a la sepultura constituye un derecho y un deber», resalta Espinoza ${ }^{8}$. Puede encontrarse ya vigorosamente defendido en la antigua Grecia: en Antígona -el drama escrito por Sófocles-, la protagonista invoca ante el rey Creonte el derecho a enterrar a su hermano, que viene de los dioses, por encima de la orden de aquel de dejar que el cadáver se pudra sin recibir sepultura por haber atacado Tebas con ayuda de fuerzas extranjeras. Otro ejemplo lo tenemos en La Ilíada, cuando el rey de Troya, Príamo, pide a Aquiles que le entregue el cadáver de su hijo Héctor, a fin de poder rendirle honores tras su trágica muerte.

Ahora bien, el tema de la sepultura nos lleva a lo siguiente: ¿se trata de un derecho de la familia, de un deber de la sociedad, o de un derecho del difunto?

Una cuestión interesante vinculada con la autonomía de la voluntad y las decisiones post mortem de la persona es lo que ocurrió hace unos años en Nueva York, cuando una mujer abrió el camino para que se autorice el entierro de las cenizas de los dueños de mascotas al lado de estas en el cementerio para perros de dicha ciudad ${ }^{9}$. $\mathrm{Al}$ respecto, vistas las cosas con detenimiento, parecería no haber mayor objeción jurídica a que una persona quiera que se entierren sus cenizas junto con su perro, en el cementerio de mascotas; pero muy diferente sería el caso en el que una persona quiera enterrar a su perro en un cementerio para humanos.

7 Juan Morales Godo, Hacia una concepción jurídica unitaria de la muerte. (Lima: Pontificia Universidad Católica del Perú, Fondo Editorial, 1997), 21.

8 Juan Espinoza Espinoza, Derecho de las personas. Tomo I: Concebido y personas naturales. (Lima: Grijley, 2012), 344.

9 Es el caso de la señora Smith, quien pidió compartir su última morada junto a las cenizas de su fiel perro Fluffy, que había muerto en el año 2008. Al fallecer ella en el año 2013, luego del referido proceso, la justicia de Nueva York autorizó que dueños y mascotas puedan ser enterrados juntos. 
Un caso pintoresco es el sucedido en Yorkshire (Reino Unido) hace unos pocos años, cuando un jardinero descubrió de casualidad la tumba de un individuo llamado Harry Potter, muerto en 1919, quien, por supuesto no tenía ninguna relación con el personaje de las novelas escritas por J. K. Rowling. Se planteó, entonces, la cuestión de si el aprovechamiento de dicho lugar como atractivo turístico podría o no considerarse una afrenta a la paz de los sepulcros. Asimismo, merece mencionarse que, en el Perú, a raíz de la muerte, en el año 2011, de un estudiante universitario que se había perdido en el valle del Colca (Arequipa), un ocurrente alcalde creó, con el objeto de promover el turismo en su ciudad, el recorrido denominado «Ruta de Ciro» con un trayecto que pasaba por los últimos lugares por donde había andado el fallecido Ciro Castillo Rojo, en una especie de «turismo negro».

Otro caso muy peculiar para el análisis jurídico es la historia de Richard Poncher. La actriz Marilyn Monroe y el beisbolista Joe Di Maggio habían comprado, cuando eran pareja, dos nichos juntos en el cementerio, uno arriba del otro. Fallecida ella, sin embargo, Di Maggio, quizás ya poco interesado en estar junto a Marilyn después de su muerte, decidió vender el nicho contiguo al de la famosa actriz. Este fue comprado por un hombre apellidado Poncher, ferviente admirador de Marilyn, quien dispuso que, cuando muriera, lo sepultaran allí, agregando a su petición que lo entierren boca abajo. Al pasar a mejor vida, su viuda cumplió con rigurosidad los poco convencionales deseos de su marido. Empero, años después, ella, agobiada por enormes deudas y a falta de mejores opciones, decidió subastar la tumba de su marido, y consiguió un postor que le ofreció nada menos que unos cuatro millones de dólares; la viuda, ni tonta ni perezosa, no dudó en aceptar y cambiar de sitio a su finado esposo. Dado que Poncher compró el nicho expresamente para estar junto a Marilyn, ¿podría alguien demandar a su viuda por no respetar la voluntad del difunto? ¿Qué derecho se estaría violando? ¿Quién sería el titular de dicho derecho?

Como acota Monge, el derecho a disponer del propio cadáver «podría entenderse como un derecho de la personalidad que se prolonga más allá de ese acontecimiento cierto pero imprevisible que es la muerte ${ }^{10}$. Dicha posibilidad de disposición nos revelaría que estamos en presencia «ya no de una especie

10 Luz Monge Talavera, "Comentario al art. 8 del Código Civil», en Código Civil comentado por los 100 mejores especialistas, varios autores (Lima: Gaceta Jurídica, 2003), 133. 
de protección póstuma de la persona, sino de previsiones normativas de respeto — no ilimitado- de una voluntad manifiesta del difunto» ${ }^{11}$.

A mayor abundamiento, puede agregarse con Cifuentes:

Si bien los derechos personalísimos son vitalicios y, por tanto, se extinguen con la muerte de la persona, hay ciertas proyecciones de su ejercicio para el tiempo posterior. En vida la persona puede disponer relativamente sobre su futuro cadáver, estableciendo su destino. [...] y esa voluntad debe ser respetada, siempre que no ataque intereses superiores de la moral y las buenas costumbres ${ }^{12}$.

Cuestión última por analizar en este punto es acerca del derecho a la sepultura del concebido. Siendo sujeto de derecho para todo cuanto le favorece, no debería caber discusión alguna, pues goza de aquel en forma similar a la persona ya nacida ${ }^{13}$. Todo ser humano fallecido, nacido o no, tiene derecho a la sepultura.

El concebido, como vida humana, tiene derechos desde la concepción. La sepultura se incluye dentro de ellos, siendo discusión aparte determinar desde qué momento de su existencia gozaría de dicho derecho, pues no será lo mismo para estos efectos un feto de un mes que uno de cuatro.

Aun cuando la legislación no haga referencia expresa al derecho a la sepultura del concebido, este le deviene por su sola condición de ser humano, de sujeto de derecho. La muerte acaba con la vida de la persona y puede hacer lo propio también con la del ser humano en gestación, volviéndose exigible en ambos casos el derecho a la sepultura.

Un caso relacionado con el indebido uso de un cadáver es el que ocurrió en Uruguay, en el año 2015, cuando un grupo de estudiantes llevó un cadáver a una fiesta en Montevideo, en la que celebraban el fin de sus estudios. Por este motivo fueron suspendidos, estableciéndose, además, como sanción adicional que tardarían un año más en recibir sus diplomas ${ }^{14}$.

11 Umberto Breccia, Lina Bigliazi Geri, Ugo Natoli y Francesco Busnelli, Derecho Civil. Normas, sujetos y relación jurídica, volumen I (Bogotá: Universidad Externado de Colombia, 1995, tomo I), 206.

12 Santos Cifuentes, Elementos de derecho civil. Parte general (Buenos Aires: Editorial Astrea, 1988), 49.

13 Juan Espinoza Espinoza, Derecho de las personas, 65.

14 «Uruguay: Estudiante de medicina usó cadáver para hacer broma», El Comercio, 21 de mayo de 2015, https://elcomercio.pe/mundo/latinoamerica/uruguay-estudiante-medicina-cadaverbroma-365392-noticia / 
Por otro lado, hace unos pocos años, se difundió la noticia de que en Estados Unidos, a una persona que había muerto, una funeraria decidió cortarle los pies porque era muy alta como para caber en ninguno de los ataúdes de los que disponía.

No cabe duda de que estamos ante actos cuestionables, ciertamente. Sin embargo, en estos casos, ¿de quién es el derecho que se ha violado? ¿Ante qué tipo de acto ilícito estamos? ¿Puede hablarse de un atentado contra la integridad física o la dignidad de quien ya no tiene vida? ¿Se trata más bien de la vulneración de algún derecho de los familiares? ¿Estaríamos ante un simple atentado contra la propiedad?

El caso resulta jurídicamente complejo, aunque es claro que, así como «el respeto por la memoria de los difuntos exige dar cierto lugar a su voluntad en cuanto al destino que tendrá su cadáver» ${ }^{15}$, también se trata de respetar su integridad y su honorabilidad ${ }^{16}$.

Los casos mencionados de uso indebido del cadáver no son un atentado contra la propiedad ${ }^{17}$, pues el cadáver no es objeto de propiedad, no tiene contenido patrimonial, como bien dice Monge Talavera ${ }^{18}$, y se halla fuera del comercio ${ }^{19}$, por lo que, en tales situaciones, se estaría más bien ante atentados contra la piedad, el respeto y la paz de los sepulcros; o, en algún caso, de un acto contra las buenas costumbres.

Puede aquí afirmarse, con Fernández Sessarego, que el cadáver, en cuanto bien jurídicamente tutelado, no es objeto de propiedad privada. El cadáver se

15 Mariano G. Morelli, «Extracción de órganos de cadáveres con fines de trasplante», 127.

16 Un caso dramático es el de George Stinney, ejecutado a los 14 años, acusado de haber asesinado a dos niñas blancas en Carolina del Sur, luego de una supuesta confesión, obtenida en forma irregular en 1944. En 2014, es decir, 70 años después, la justicia estadounidense declaró irregular la ejecución.

17 En este caso no podría hablarse de un derecho de propiedad sobre el cadáver, pues este no tiene naturaleza ni contenido patrimonial, expresando más bien «intereses de índole exquisitamente espiritual» (Umberto Breccia, Lina Bigliazi Geri, Ugo Natoli y Francesco Busnelli, Derecho Civil. Normas, sujetos y relación jurídica, 206).

18 «El cuerpo humano es inalienable; en vida o después de su muerte no puede ser objeto de un derecho patrimonial», a lo que se debe agregar que «el reconocimiento de la facultad de disponer del cadáver no implica la atribución de un derecho de propiedad». (Luz Monge Talavera, comentario al art. 8 del Código Civil, 134).

19 «... pueden ser objeto del derecho de propiedad todas las cosas, corporales o incorporales, siempre que sean susceptibles de apropiación, presten una utilidad económica a su titular y estén determinadas» (Eduardo Serrano Alonso y Eduardo Serrano Gómez, Manual de Derechos Reales. Madrid: Edisofer, S. L., 2005, 96). 
encuentra sujeto a las normas sanitarias de orden público y tiene el destino que la ley le señala: ser objeto de piedad y respeto, de sepultura, apto para trasplantes, experimentación y enseñanza, según el caso. Está fuera del comercio de los hombres ${ }^{20}$.

Una interesante sentencia en relación con la disposición del cadáver vinculada con un dramático y triste caso- es la expedida por el 26. ${ }^{\circ}$ Juzgado Especializado en lo Penal de la Corte Superior de Lima, ante la decisión de EsSalud de negarse a entregar a unos padres el cadáver de su hijo recientemente abortado en forma natural; dicha institución argumentaba que el cadáver no había alcanzado el peso establecido por una directiva institucional, según la cual los fetos de menos de 500 gramos son considerados un aborto, y, en consecuencia, no se le podía extender el certificado de defunción. El juez, al final del proceso, resolvió reconocer el derecho de los padres de sepultar el cadáver del niño ${ }^{21}$.

Al hablar del derecho a la sepultura, nos encontramos ante un derecho de todo ser humano, el cual se ejerce post mortem. Podría pensarse que, en este caso, el entierro del cadáver, más que un derecho del fallecido, es un deber y un derecho de los vivos, el cual se cumple por razones de salubridad y orden público; pero resulta evidente que dicha sepultura tiene que ver también -y fundamentalmente - con la consideración de la persona, siendo un derecho que tiene la particularidad de que se genera en vida, pero solo puede ejecutarse con la muerte.

\section{El testamento, el seguro de vida, la donación de órganos y otros derechos que se ejecutan post mortem}

Para determinar si los muertos tienen o no derechos, podemos partir del análisis del testamento: cuando una persona fallece y deja uno, este tiene que respetarse y ejecutarse tras su muerte. Así, como señala Salazar, «Los muertos también tienen derechos: derecho, sobre todo, a que sus bienes se administren según su última voluntad»²2.

20 Carlos Fernández Sessarego, Derecho de las personas. Exposición de motivos y comentarios al libro primero del Código Civil, 10. ${ }^{a}$ ed. (Lima: Grijley, 2007), 65.

21 Para más detalle del caso, véase: Clara Mosquera, «Derecho de la madre a sepultar a su feto», La Ley, n. ${ }^{\circ}$ 69, (octubre de 2013), 15.

22 Federico Salazar, «Los muertos también tienen derechos», La República, 8 de abril de 2007. 
Sin embargo, podría observarse que la exigencia de cumplir el testamento no reposa en un derecho del difunto, sino en el ejercicio de un derecho de los beneficiarios. Por tanto, podría parecer que el derecho sería de estos, no del de cujus.

El seguro de vida podría parecer un ejemplo de que los muertos sí tienen derechos, pues, fallecida la persona que lo contrató, debe procederse a su pago en favor del beneficiario. Empero, algún crítico podría hacer aquí una objeción similar a la del testamento: no es que estemos ante un derecho del difunto, sino ante un atributo del beneficiario del seguro.

Cuando nos encontramos ante una disposición de órganos post mortem, esta tiene que ser cumplida, aun cuando exista oposición de los familiares (más allá de que en la práctica muchos médicos se sientan cohibidos de hacerlo cuando no cuentan con la aprobación de la familia, sea por temor a ganarse un pleito o por desconocimiento de la ley). ¿Sería este un ejemplo de que los muertos sí tienen derechos? El mismo objetor podría decir también que, como en los casos anteriores, cuando se exige proceder con la cesión de órganos, lo que se estaría haciendo es atender un derecho de los beneficiarios, no del extinto donante.

Si pensamos en las fundaciones, veremos que toda persona tiene derecho a constituirlas para después de su fallecimiento. ¿Sería este, entonces, un mejor ejemplo de un derecho post mortem? ¿O también habría que decir que el único derecho implicado es el de los beneficiarios de la fundación?

De lo expuesto, queda claro que el respeto a la voluntad testamentaria, el pago del seguro de vida, la cesión de órganos post mortem y la constitución de una fundación por vía testamentaria tienen en común que todos son casos de derechos que se generan en vida, pero que se ejecutan a la muerte de la persona. Y, si bien tienen ellos beneficiarios con derecho a aquellos, no puede negarse que, en realidad, estamos también ante casos en los que nos sentimos llamados a respetar la voluntad de una persona ya fallecida.

\section{Los derechos de autor como derechos post mortem}

Fallecida la persona, los herederos tienen derecho a aprovechar los derechos patrimoniales del autor hasta que la obra pase a ser de dominio público; la autoría moral de la obra, sin embargo, será siempre de su autor. Nadie puede publicar Romeo y Julieta consignando como autor a alguien distinto de William 
Shakespeare. Pasarán los siglos y siempre Chabuca Granda será la autora de «La flor de la canela», como J. K. Rowling lo será de las novelas de Harry Potter. No se trata solo de la protección del acervo cultural: ¿no estaríamos en este caso, por tanto, ante un derecho en favor de los difuntos?

En cuanto a la protección legal de estos derechos, como señala Villarreal (2003), es de mencionar que:

... un campo en particular en el que están bien reconocidos y garantizados los derechos post mortem es el de propiedad intelectual. En el marco de la Organización Mundial de la Propiedad Intelectual (OMPI), a favor de los derechos morales de los autores y compositores con posterioridad a su fallecimiento está la Convención de Berna para la Protección de las Obras Literarias y Artísticas (1971, art. 6 bis, 7, 7 bis y 14 ter) y de los artistas intérpretes o ejecutantes está el Tratado sobre Interpretación y Ejecución o Fonogramas (1996, art. 5) (p. 11) ${ }^{23}$.

\section{Imagen, identidad y honor como derechos post mortem}

Años después de haber fallecido la legendaria Marlene Dietrich, una empresa empezó a comercializar diversos productos (souvenirs) con la imagen de la famosa actriz. Como ella estaba muerta y ya no podía reclamar sus derechos, sus herederos exigieron las regalías correspondientes, puesto que el nombre de la Dietrich había empezado a usarse hasta para denominar a modelos de autos. De esta manera, la imagen fue protegida en beneficio de los derechos económicos de los herederos.

Pero supongamos ahora que, estando de paso por el Perú, la cantante Jennifer López falleciera de manera súbita. Antes de ser devuelto su cadáver a su país, su cuerpo es enviado a una funeraria para su preparación respectiva; aprovechándose de la ocasión, un empleado pervertido empieza a tomar fotos del cuerpo desnudo de la bella intérprete, poniéndola en diversas poses de carácter sensual, generando, así, un material gráfico que el pecaminoso trabajador usa para publicar un calendario y venderlo.

23 Héctor Villarreal, «Fundamentos de los derechos post mortem de la persona y su situación en la ciudad de México». (2013), 11, https://www.academia.edu/1131514/Fundamento_de_ los_derechos_post_mortem_de_la_persona_y_su_situación_en_la_Ciudad_de_México. 
Obviamente estaríamos aquí ante una barbaridad, una violación de derechos, un acto vil y despreciable, sin duda; mas ¿qué derecho(s) se estaría(n) vulnerando? ¿Al honor? ¿A la imagen? ¿A la intimidad? ¿A la dignidad? El asunto no queda allí, pues junto con tales interrogantes hay que preguntarnos también de quién sería el derecho que se estaría afectando: ¿de Jennifer López o de sus herederos?

Parecería que de ella, pues es a ella a quien la han fotografiado sin su permiso, exhibiendo su intimidad. ¡El problema es que ya está muerta! ¿Podría decirse entonces que estaríamos violando algún derecho de su familia? Asumamos que así sea; la pregunta que vendría a continuación sería: ¿y si la familia aceptara una oferta del empleado de la funeraria para ir a medias con las ganancias por el calendario y venderlo en todo el mundo, ya no habría problema alguno?

Por supuesto que seguiría habiéndolo, lo cual demuestra que lo que está de por medio, en esencia, son los derechos de la cantante, aun cuando estuviera muerta. $\mathrm{Y}$ es que una persona tiene derechos de los que nadie puede disponer, ni siquiera la propia familia.

Cuando alguien yace muerto en la calle, solemos taparlo con una frazada o lo que pueda servir para el efecto, lo cual realizamos más que por alguna consideración con la familia de la víctima, por la propia persona difunta que tenemos en frente, como afirma Cantor ${ }^{24}$. Hay aquí una cuestión de sensibilidad, de decoro, de compasión, de humanidad. No conocemos en absoluto a la persona, menos a su familia, pero igual sabemos que hay que tratarla con piedad y respeto.

Por ello es que, cuando un canal de televisión exhibe el cuerpo maltratado de una persona asesinada, sentimos malestar, indignación. Nada justifica la exposición del cuerpo de una persona. Ello constituye un flagrante atentado contra el derecho a la intimidad.

Un caso bastante recurrente en la prensa es la fotografía de personas muertas en accidentes de tránsito. Para el efecto, los medios invocan razones de interés público y el derecho a la información, pero surge aquí una pregunta: ¿publicó algún medio la foto de Diana de Gales agonizando o muerta,

24 «Even if cadavers cannot sense the actual violation of a lifetime's legacy, their image and identity are things they have worked to establish that can be harmed» (Norman Cantor, After We Die, 39). 
después de su fatal accidente? Ciertamente que no; no por la reina, el príncipe Carlos o sus hijos: simplemente por ella. Y es que no había ninguna necesidad de divulgar su foto ensangrentada: bastaba la foto del auto chocado para tener idea de la gravedad del accidente; no era necesario ver la imagen desgarradora de la víctima para comprender la magnitud de la tragedia.

Hay fotos terribles que se publican con motivo de atentados: un padre cargando el cadáver de un hijo, un hombre con su hermano muerto sobre sus piernas, una madre llorando en la puerta de un hospital por la suerte de sus hijos. Como dice el periodista español Francisco Jiménez: una persona muerta en la irremediable indefensión de los cadáveres, sigue siendo una persona, no solo unos restos, no solo es un muerto. Incluso es discutible que la familia - a la que ni siquiera se le pide hoy ese permiso - tenga derecho a permitir que se exhiban ciertas imágenes de los muertos, aun cuando sea con intención propagandista contra el terrorismo ${ }^{25}$.

Se suele justificar la difusión de este tipo de imágenes apelando a que ellas sirven para sensibilizar a las personas, mas esto parece discutible. Todos comprendemos la magnitud del salvaje atentado contra las Torres Gemelas en Estados Unidos el 11 de setiembre de 2001, pero ¿algún medio difundió la foto de un solo cadáver de los miles de personas que murieron, para que el público pueda captar la dimensión del acto? Ninguno, y es que en verdad no era necesario hacerlo.

Otro caso interesante vinculado con el derecho a la intimidad y los muertos es el del torero Paquirri -el famoso Francisco Rivera, esposo de la cantante Isabel Pantoja-, que en setiembre de 1984 murió en plena faena, cogido por un toro llamado Avispado. Inmediatamente después de sufrir la cornada, el bravo torero fue llevado a la enfermería de la plaza, pero no sobrevivió. Esa noche, en el noticiero, se difundieron las imágenes de sus últimos minutos de vida. Días después, una empresa sacó a la venta unos CD sobre la vida de Paquirri, en donde se incluían escenas de la terrible cogida y del momento de su muerte. La viuda, entonces, presentó una demanda, en la que invocaba el derecho a la intimidad y a la imagen, entre otras consideraciones. Pasadas todas las instancias, al final el Tribunal Constitucional español falló diciendo que los medios tenían derecho de filmar y difundir la corrida, y hasta la cogida misma, pero que ese derecho a la información terminó cuando Paquirri

25 Federico Jiménez Lozanitos, «Imágenes y muertos», en El Mundo, 2 de diciembre de 2003. 
entró a la enfermería del coso. Empero, el Tribunal no dijo que se hubiera violado el derecho a la intimidad del torero - pues ya estaba muerto-, sino el de su familia. Cabe preguntarnos entonces: ¿si no hubiera tenido familia, no se hubiera estado violando ningún derecho?

Por otro lado, ¿qué pasaría si una persona empezara a decir públicamente que tal fallecido cantante era un acosador sexual cuando no lo era? ¿Se estaría afectando un derecho de él o de su familia? ¿Acaso, si no tuviera familia, no podría reclamar cualquier persona en defensa del honor del difunto? Si decimos que Juan es un corrupto, ¿afecta ello la honorabilidad de él o la de su familia? Si reclamamos porque alguien habla mal de un hermano nuestro, ¿lo hacemos por nosotros y no por nuestro hermano?

\section{La personalidad pretérita trascendente como sustento de los derechos post mortem de la persona}

La muerte disuelve el matrimonio y extingue la patria potestad, entre otros efectos, pero el padre sigue siendo padre y el hijo sigue siendo hijo. Del mismo modo, si el fallecido era escritor o compositor, el autor sigue siendo autor. $Y$ es que cuando la persona muere, no por ello pierde todos sus derechos, incluidos el honor y la dignidad.

A pesar del hecho de la muerte, «[1]a protección concedida a la persona se prolonga también en alguna medida al cadáver» ${ }^{26}$, y es que «existe cierta continuidad de la persona a través de sus obras o bienes, mediante su voluntad objetivada en un testamento o en un acto constitutivo de una fundación ${ }^{27}$. Como afirman Bergoglio, Bertoldi y Lloveras ${ }^{28}$, «el principio de que la personalidad termina con la vida está limitado por otra idea según la cual el respeto póstumo que se debe a quien fue persona atribuye a su voluntad una virtud "ultra activa", que opera después del fallecimiento del declarante».

26 Alfredo Orgaz, Derecho civil argentino. Personas individuales, 2. ${ }^{a}$ ed. (Córdoba: Ediciones Assandri, 1961), 132.

27 Carlos Fernández Sessarego, Derecho de las personas. Exposición de motivos y comentarios al libro primero del Código Civil Peruano (Grijley, 2007), 217.

28 María Teresa Bergoglio, María Virginia Bertoldi de Fourcade y María Emilia Lloveras de Resk. Lecciones de derecho civil. Personas naturales y jurídicas (Córdoba: Advocatus, 1990), 106. 
Ocurre entonces que, como dice Lacalle, «[a]unque el fallecimiento extingue la personalidad y, por tanto, los derechos de la persona, se sigue protegiendo durante un tiempo lo que la doctrina llama la personalidad pretérita, o la honra de los difuntos» ${ }^{29}$.

También Rogel señala que se puede hablar de una personalidad pretérita $^{30}$, de la operatividad de la voluntad del fallecido, ya sea para el cumplimiento de su testamento o la constitución póstuma de una fundación, pero también del derecho a la buena fama y reputación, del reconocimiento de la propiedad intelectual «post mortem auctories» (p. 38).

La idea es desarrollada con más detalle por Lacruz Berdejo y otros, al señalar que, extinguida la persona, deja de ser centro de poder y de responsabilidad, pero persisten la operancia de su voluntad pretérita (expresada en un testamento, sobre todo) y el derecho a la buena fama y a la propia reputación, que pueden hacer efectivo los herederos y los más próximos parientes ${ }^{31}$.

También se refiere a la voluntad pretérita, siguiendo a los mismos autores, Lete del Río ${ }^{32}$.

Así entonces, como explica Carbonnier, podemos decir que:

El derecho admite una especie de prolongación de la personalidad después de la muerte que viene a ser una tutela póstuma de la persona; así sucede que las difamaciones o injurias dirigidas contra la memoria de los muertos son penalmente sancionables y también pueden dar lugar a indemnización ${ }^{33}$.

En el Perú, a tenor de lo consignado en el artículo 138 del Código Penal, lo que se protege de manera literal es la memoria de la persona fallecida, no la de sus familiares.

29 María Lacalle Noriega, La persona como sujeto de derecho (Madrid: Dykinson, 2013), 239.

30 Otros autores, como María E. Cobas, «Protección post mortem de los derechos de la personalidad. Reflexionando sobre la cuestión», Revista Boliviana de Derecho, n. ${ }^{\circ} 15$ (2013), 112-129, 115, prefieren más el concepto de memoria defuncti, que "personalidad pretérita", considerando que con la muerte se extingue la personalidad jurídica.

31 José Luis Lacruz Berdejo, Francisco de Asís Sancho Rebullida, Agustín Luna Serrano, Jesús Delgado Echevarría, Francisco Rivero Hernández y Joaquín Rams Albesa, Elementos del derecho civil. Parte general (Madrid: Dykinson, 2010), 23.

32 José M. Lete del Río, Derecho de la persona (Madrid: Dykinson, 3. a ed., 1996), 54.

33 Jean Carbonnier, Derecho civil I. Disciplina general y derecho de las personas (Barcelona: Bosch, 1960), 223. 
En todo caso, agrega el maestro francés, «[1]o más destacado y sorprendente es el fenómeno (reconocido por el derecho) por el que la voluntad humana prolonga su poder más allá de la muerte y cuya manifestación más frecuente es el testamento» ${ }^{34}$.

Cabe recalcar, en consecuencia con lo expuesto, que no se trata solo de proteger los derechos de terceros sobrevivientes al fallecido, sino de derechos que tienen que ver de forma directa con este último ${ }^{35}$.

Como dice Espinoza:

El derecho tutela, más allá de la existencia de las personas, determinadas situaciones jurídicas, vale decir, la intimidad, la identidad, la reputación y esto sucede independientemente de los intereses que puedan tener sus parientes. Aquel que ha vivido es protegido en cuanto tal: la muerte de un sujeto no es una suerte de desaparición instantánea en el mundo de las relaciones jurídicas. Si en estos casos no se puede hablar de "derechos", no se puede decir lo mismo por cuanto respecta a la protección "ultraexistencial" del sujeto. Si una persona muere no se puede ignorar la esfera privada que ha tenido y divulgar noticias íntimas sobre su vida, ni se puede alterar la proyección social que su personalidad tenía en vida, entre otros aspectos ${ }^{36}$.

Como hemos dicho ya, en el caso del testamento, del seguro de vida o de la cesión de órganos post mortem, siendo objetivos y claros, cuando se ejecutan, no solo se atiende a los derechos de los beneficiarios, sino también social, moral y jurídicamente a los deseos del fallecido. Técnicamente, no es que el muerto tenga derechos, sino que las personas, estando en vida, tienen ciertos derechos que se ejecutan post mortem. Estamos ante una prolongación de la personalidad de un ser humano al que, si bien ya no existe más físicamente, le trascienden ciertos atributos y derechos inherentes a su condición, a su historia, a su proyección en el espacio y en el tiempo, configurando una dignidad póstuma.

Las personas, a lo largo de su vida, no solo adquieren bienes; se hacen también de un buen nombre, de un prestigio, crean cosas, establecen relaciones y producen obras que les perviven. Puede que llame la atención cómo

34 Carbonnier. Derecho civil I, 60.

35 Carlos Lasarte, Parte general y derecho de la persona. Principios de derecho civil (Madrid: Marcial Pons, 15. ${ }^{a}$ ed., 2009, tomo I), 157.

36 Espinoza, Derecho de las personas, 351. 
puede hablarse de derechos y obligaciones respecto de quien no tiene existencia física, pero en el propio derecho encontramos situaciones de derechos y deberes que no tienen un sustrato material, pero que pueden ser jurídicamente relevantes, como las personas jurídicas o la idea de patria.

Por lo demás, no es extraña en el derecho la existencia de derechos que solo empiezan a ejecutarse y a tener sentido con la muerte. Frente a quienes consideran que, habiendo fallecido la persona, sus actos pierden valor $\mathrm{y}$, por tanto, no debería reconocérsele jurídicamente, observa Morelli que:

... el ordenamiento jurídico reconoce, en otras áreas "actos mortis causa" que si bien se realizan en vida, no tendrían sentido si su voluntad no se respetara después de su muerte $[\ldots]$ ¿Qué sentido tendría un testamento cuyo valor desapareciera una vez fallecida la persona? Parte del deseo natural del ser humano de trascender a su muerte se manifiesta en la pretensión de que su voluntad respecto de algunos elementos suyos sea respetada incluso cuando haya dejado de convivir entre los mortales ${ }^{37}$.

En el plano legislativo, resalta Lasarte la Ley Orgánica 1/1982, del 5 de mayo, en España, cuyo artículo 4 faculta para ejercer las acciones de protección civil del honor, intimidad o imagen de la persona a los herederos o parientes, y, en su defecto, al Ministerio Fiscal, pues, como dice la exposición de motivos de dicha ley:

Aunque la muerte del sujeto de derecho extingue los derechos de la personalidad, la memoria de aquel constituye una prolongación de esta última que debe ser tutelada por el Derecho; y por ello, se atribuye la protección en el caso de que la lesión se hubiera producido después del fallecimiento de una persona a quien esta hubiera designado en su testamento; en defecto de ella, a los parientes supervivientes y, en último término, al Ministerio Fiscal con una limitación temporal que se ha estimado prudente ${ }^{38}$.

37 Morelli, «Extracción de órganos de cadáveres con fines de trasplante...», 129.

38 Lasarte, Parte general y derecho de la persona, 158. 
Dicha norma, como señalan Lacruz Berdejo y otros ${ }^{39}$, resulta fundamental para la defensa de los derechos al honor, intimidad e imagen del fallecido ${ }^{40}$.

\section{La dignidad como fundamento de los derechos post mortem}

El médico, los enfermeros, los empleados de una funeraria, los estudiantes de medicina, el enemigo en caso de guerra, todos en general tenemos el deber de respetar la condición humana del cadáver, aun después de muerta la persona, en reconocimiento a su dignidad.

Como se ha señalado ya, «la dignidad del ser humano prevalece aún después de la muerte» ${ }^{41}$, pudiendo hacerse referencia al caso Colón Vda. de Rivera vs. Romero Barceló, 112 DPR, planteado en Puerto Rico, en el que se presentó una acción para detener la publicación, como parte de una campaña publicitaria, de una foto del cadáver de una persona asesinada en un asalto. El tribunal resolvió que dicho uso violaba los derechos constitucionales a la intimidad, personalidad, vida privada y honor ${ }^{42}$.

A mayor abundamiento, pueden citarse aquí las palabras de González:

... el hecho de la muerte no convierte al cuerpo humano (cadáver) en cosa que pueda ser objeto de comercio jurídico. Aunque el alma se haya separado del cuerpo, la dignidad de la persona se extiende más allá de la muerte y exige el debido respeto a lo que en vida constituyó una unidad con el alma ${ }^{43}$.

39 Agregan los mismos autores: «En todos estos casos, los herederos o parientes reclaman derechos del difunto que subsisten en cuanto atributos de su personalidad pretérita; el sujeto ni pervive por ello, pero, aun desaparecido, queda un resto de derechos extrapatrimoniales que, en homenaje a una existencia anterior, pueden ser hechos valer en favor - sobre todode la buena memoria del difunto, por ciertas personas como gestores de esa buena memoria: no como derechos propios» (Lacruz Berdejo y otros, Elementos del derecho civil, 2).

40 Dora Nevares-Muñiz, «Deliberación en bioderecho», Revista Lumen n. ${ }^{\circ} 9$ (2013), 132.

41 Nevares-Muñiz, «Deliberación en bioderecho», 132.

42 Nevares-Muñiz, «Deliberación en bioderecho», 132.

43 Jesús González Pérez, La Dignidad de la Persona (Pamplona: Civitas-Thomson Reuters, 2011), 177. 
La dignidad vendría a ser, entonces, no solo uno de los derechos post mortem de la persona, sino el fundamento mismo de dichos derechos ${ }^{44}$.

Se debe agregar — como sostiene Guzmán- que en una sociedad amorfa como la que vivimos, con una profunda crisis de valores y una cantidad emergente de actos éticamente reprobables sobre cadáveres, "y más aún frente al vertiginoso avance biotecnológico, toca al Derecho precautelar, lo más holísticamente posible, la sana institución del respeto debido a los muertos» ${ }^{45}$.

\section{A manera de conclusión}

De lo expuesto en las páginas que anteceden, no es que los muertos cuenten con derechos de por sí, sino en tanto su condición pretérita de personas; los tienen en forma limitada, restringida, sin poder ejercerlos por sí mismos, por cierto, pero derechos, al fin y al cabo, como una prolongación trascendente de su personalidad y sobre la base de una dignidad póstuma que tiene el ser humano.

Hablar de «derechos de los muertos» no es técnicamente exacto, pues solo las personas los tienen; pero vale el término si lo que quiere decirse con él es que tenemos derechos que se ejercen luego de haber muerto. ${ }^{46} \mathrm{Y}$ es que el yo no se acaba con la muerte ${ }^{47}$.

44 Como sostiene Héctor Villarreal («Fundamentos de los derechos post mortem»), «La ignidad humana permite fundamentar que hay derechos de la persona que trascienden a su fallecimiento, a los cuales se les puede llamar derechos post mortem de la persona. Estos son el cumplimiento de la voluntad del destino de las propiedades, el tratamiento decoroso de su cadáver y restos, el respeto a la honra y a la personalidad jurídica».

45 Jorge Armando Guzmán Lozano, «La naturaleza jurídica del cadáver: revisión y tendencia». Prudentia Juris n. ${ }^{\circ} 86$ (2018), 15.

46 Marcial Rubio Correa, «El ser humano como persona natural» en Para leer el Código Civil, vol. XII (Lima: Pontificia Universidad Católica del Perú. 1995), 61. Adicionalmente, coincidiendo con Villarreal («Fundamentos de los derechos post mortem»), podemos decir que: «La expresión derechos de los muertos sería incorrecta si con ella quisiéramos decir que los cadáveres tienen derechos, pues solo las personas son sujetos de ellos; pero puede ser válida si el sentido es que las personas conservan derechos después de su muerte, puesto que su dignidad no acaba con su fallecimiento».

47 Enrique Alarcón, «Libertad y necesidad», Anuario Filosófico, XLIII/I (2010), 43. Agrega el mismo autor que: «Hasta tal punto advertimos intuitivamente el carácter único e irremplazable de la identidad personal que todas las culturas humanas asumen que el yo no desaparece con la muerte». 
En algunos casos, se trata de derechos que la persona tuvo cuando estaba viva y que se conservan post mortem. En otros casos, son derechos que le devienen o que se vuelven exigibles recién con la muerte. Estamos ante derechos pretéritos que, nacidos antes, se ejercen o se siguen ejerciendo luego de la muerte. Los muertos tienen incluso un derecho a la paz, como reconoce Hurtado Pozo, el cual puede verse violado en forma agravada en el caso de la venta de órganos o tejidos de cadáveres ${ }^{48}$.

La persona fallecida no es un simple objeto; por esta razón, por ejemplo, no puede aceptarse el uso de su cadáver para pruebas de seguridad vehicular.

La jurisprudencia argentina, sobre la base del artículo 15 de su anterior Código Civil e interpretando de forma de forma sistemática el derecho, señala que debe prevalecer la voluntad del causante, incluso sobre las creencias religiosas de los herederos ${ }^{49}$.

Nuestra capacidad para reconocer y respetar los derechos de quien no está ya para defenderse pone a prueba nuestra entereza, nuestra altura, nuestra integridad como personas. Mas no vaya a creerse por ello que es solo una cuestión de nuevas leyes, pues también se trata de incumplimiento. La oposición de la familia en el caso de la cesión de órganos tiene que ver con falsas creencias, prejuicios, o simplemente desconocimiento; no es en el Perú, al menos, un problema de falta de leyes; ocurre que no se cumplen las que ya existen.

Al iniciar la presente investigación, nos planteamos algunas hipótesis. Con respecto a ellas, luego de haber sido sometidas a validación, podemos concluir lo siguiente:

Primera hipótesis: «Las personas fallecidas, aunque con su muerte dejan de ser sujetos de derecho, mantienen algunos que les perviven. Adquieren, de esta manera un estatus especial». Al respecto, consideramos que, en efecto si bien el fallecido ya no es persona, algunos efectos de la personalidad que le antecedieron pueden prolongarse con posterioridad de su muerte.

48 José Hurtado Pozo, «Relaciones entre el derecho penal y el derecho civil respecto al delito de hurto en el Código Penal peruano», Revista Oficial del Poder Judicial, año 4-5, n. ${ }^{\circ}$ y 7, 2010-2011, 231-253.

49 Jorge E. Córdoba y Julio C. Sánchez Torres, Derechos personalísimos (o de la personalidad o iura in persona ipsa) (Córdoba: Editorial Alveroni, 1996), 45. 
Segunda hipótesis: «Existen disposiciones del fallecido que son de obligatorio cumplimiento, sin que los familiares puedan oponerse a ellas». Sobre el particular, por cierto existen disposiciones, como las efectuadas en un testamento o sobre la donación de órganos, que deben respetarse y ejecutarse en tanto cumplan con las condiciones establecidas en el ordenamiento jurídico.

Tercera hipótesis: «Debe optimizarse la legislación y la interpretación judicial en el tratamiento de algunas materias específicas, como en el caso del concebido no nacido, la disposición de los órganos de la persona en general, el uso de los cadáveres, el destino de las cenizas de los difuntos [...], el manejo de los casos de criopreservación, la disposición de los genes del fallecido, entre otras cuestiones». En este punto, estimamos importante optimizar el tratamiento de estos temas en el sistema jurídico a partir del concepto de «personalidad pretérita trascendente».

En Alemania, hace unos años, un artista en una galería del metro hizo una exhibición de esqueletos humanos realizando diversas actividades de la vida cotidiana: cocinando, jugando, conversando y hasta haciendo el amor; a raíz de esta última escena, un ciudadano berlinés se quejó ante la justicia germana, la cual ordenó retirarla de la exposición por un asunto de decoro. Y es que los restos de una persona no pueden, pues, ser usados para cualquier propósito.

La personalidad jurídica - finalmente, una noción abstracta- trasciende a la persona en cuanto a su existencia física. Reconocer los derechos post mortem de la persona implica admitir que el ser humano no es solo existencia, sino también trascendencia. No podemos decir que una persona mantiene presencia en el tiempo solo en cuanto a autor, sino, además, como ser humano, teniendo en cuenta su buen nombre o su memoria.

El propio sistema jurídico permite que se respete la intimidad de aquella persona que dejó establecido que, durante algunas décadas, no se publique su autobiografía o una novela que pueda haber escrito en vida y que prefiere que no se haga pública. Los sucesores y la sociedad en general deben respetar con rigurosidad dicho acto de voluntad en el transcurso de dicho periodo. ¿Qué mejor ejemplo de la existencia de derechos post mortem de la persona?

Por último, en tiempos en los que se vulneran derechos humanos de las personas en diversas formas alrededor del mundo, parecería que lo fundamental es la protección de las personas vivas. Claro que sí, pero también es cierto que en el trato que damos a nuestros muertos demostramos al final lo humanos que somos o cómo, estando aún en vida, podemos dejar de serlo. 


\section{REFERENCIAS}

Alarcón, Enrique. «Libertad y necesidad». Anuario Filosófico XLIII/I (2010).

Bergoglio, María Teresa, María Virginia Bertoldi de Fourcade, y María Emilia Lloveras de Resk. Lecciones de derecho civil. Personas naturales y jurídicas. Córdoba: Advocatus, 1990.

Breccia, Umberto, Lina Bigliazi Geri, Ugo Natoli y Francesco Busnelli. Derecho Civil. Normas, sujetos y relación jurídica, tomo I, volumen I. Bogotá: Universidad Externado de Colombia, 1995.

Cantor, Norman L. After we die: The life and times of the human cadaver. Washington DC: Georgetown University Press, 2010.

Carbonnier, Jean. Derecho civil I. Disciplina general y derecho de las personas. Barcelona: Bosch, 1960.

Cifuentes, Santos. Elementos de derecho civil. Parte general. Buenos Aires: Editorial Astrea, 1988.

Cobas, María E. «Protección post mortem de los derechos de la personalidad. Reflexionando sobre la cuestión». Revista Boliviana de Derecho, n 15 (2013): 112-129.

Córdoba, Jorge E. y Julio C. Sánchez Torres. Derechos personalísimos (o de la personalidad $o$ iura in persona ipsa). Córdoba: Editorial Alveroni, 1996.

Espinoza Espinoza, Juan. Derecho de las personas, tomo I: Concebido y personas naturales. Lima: Grijley, 2012.

Fernández Sessarego, Carlos. Derecho de las personas. Exposición de motivos y comentarios al libro primero del Código Civil, 10. a ed. Lima: Grijley, 2007.

González Pérez, Jesús. La dignidad de la persona. Pamplona: Civitas-Thomson Reuters, 2011.

Guzmán Lozano, Jorge Armando. «La naturaleza jurídica del cadáver: revisión y tendencia». Prudentia Juris n. ${ }^{\circ} 86$ (2018).

Hurtado Pozo, José. «Relaciones entre el derecho penal y el derecho civil respecto al delito de hurto en el Código Penal peruano». Revista Oficial del Poder Judicial 4-5, n. ${ }^{\circ} 6$ y 7 (2010-2011).

Jiménez Lozanitos, Federico. «Imágenes y muertos». El Mundo, 2 de diciembre de 2003. Lacalle Noriega, María. La persona como sujeto de derecho. Madrid: Dykinson, 2013. 
Lacruz Berdejo, José Luis, Francisco de Asís Sancho Rebullida, Agustín Luna Serrano, Jesús Delgado Echevarría, Francisco Rivero Hernández y Joaquín Rams Albesa. Elementos del derecho civil. Parte general. Madrid: Dykinson, 2010.

Lasarte, Carlos. Parte general y derecho de la persona. Principios de derecho civil, tomo I, 15. ${ }^{\text {. }}$ Ed. Madrid: Marcial Pons, 2009.

Lete del Río, José M. Derecho de la persona, 3. . ed. Madrid: Dykinson, 1996.

Monge Talavera, Luz. «Comentario al art. 8 del Código Civil». En Código Civil comentado por los 100 mejores especialistas, varios autores. Lima: Gaceta Jurídica, 2003.

Morales Godo, Juan. Hacia una concepción jurídica unitaria de la muerte. Lima: Pontificia Universidad Católica del Perú, 1997.

Morelli, Mariano G. «Extracción de órganos de cadáveres con fines de trasplante. Voluntariedad y consentimiento presunto». Vida y Ética, n. ${ }^{\circ} 2$ (2009). https:// repositorio.uca.edu.ar/bitstream/123456789/1504/1/extraccion-organoscadaveres-consentimiento-presunto.pdf.

Mosquera, Clara. «Derecho de la madre a sepultar a su feto». La Ley, n. ${ }^{\circ}$ 69, (octubre de 2013).

Nevares-Muñiz, Dora. «Deliberación en bioderecho». Revista Lumen, n. ${ }^{\circ} 9$ (2013).

Orgaz, Alfredo. Derecho civil argentino. Personas individuales, 2. ${ }^{\text {a }}$ ed. Córdoba: Ediciones Assandri, 1961.

Ramos Gutiérrez, Mercedes. «La protección de la memoria defuncti». Tesis doctoral, Universidad de Salamanca, 2012. http://gredos.usal.es/jspui/ bitstream/10366/121403/1/DDP_Ramos-GutierrezMercedes_Tesis.pdf.

Rubio Correa, Marcial. «El ser humano como persona natural». En Para leer el Código Civil, vol. XII. Lima: Pontificia Universidad Católica del Perú, 1995.

Salazar, Federico. «Los muertos también tienen derechos». La República, 8 de abril de 2007.

Serrano Alonso, Eduardo y Eduardo Serrano Gómez. Manual de derechos reales. Madrid: Edisofer S.L., 2005.

Trigg, Roger. Entre la cultura y la genética. Aspectos filosóficos de la sociobiología. México: Fondo de Cultura Económica, 1989. «Uruguay: estudiante de medicina usó cadáver para hacer broma». El Comercio, 21 de mayo de 2015. https:/ / elcomercio. pe/mundo/latinoamerica/uruguay-estudiante-medicina-cadaverbroma-365392noticia/. 
Villarreal, Héctor. Fundamentos de los derechos post mortem de la persona y su situación en la ciudad de México, 2013. https://www.academia.edu/1131514/ Fundamento_de_los_derechos_post_mortem_de_la_persona_y_su_situación_ en_la_Ciudad_de_México.

\section{Sobre el autor}

Profesor de las facultades de Derecho de la Universidad ESAN, la Universidad de Lima y la Universidad Femenina del Sagrado Corazón (Unifé); investigador del Instituto de Investigación Científica (IDIC) de la Universidad de Lima, doctorando en Derecho, magíster en Derecho Civil, magíster en Bioética y Biojurídica; miembro de la Pontificia Academia para la Vida y de la Academia de Derecho y Ciencias Sociales de Córdoba. 
